\title{
Bronchoscopic Lung Volume Reduction: A Window for the Future?
}

\author{
Demosthenes Bouros $^{a}$ Marios E. Froudarakis ${ }^{b}$ \\ a Department of Pneumonology, University Hospital of Alexandroupolis, Demokritos University of Thrace, \\ Alexandroupolis, and bepartment of Pneumonology, University Hospital of Iraklion, University of Crete \\ Medical School, Iraklion, Greece
}

This editorial refers to the article by Toma et al., published in Respiration 2003;70:658-664.

Lung volume reduction (LVR) surgery (LVRS) is an interesting therapeutic option which has been developed over the last decade in patients with end-stage emphysema. Initially cohort studies [1-3] and then randomized trials versus medical treatment [4] have demonstrated that lung function, exercise capacity, and quality of life are improved after LVRS.

However, many questions remain unanswered. Recent reports showed that the mortality rate after LVRS remains increased (5\%) [4, 5] in patients with a $\mathrm{FEV}_{1}<20 \%$ predicted or either a very low diffusing capacity of $\mathrm{CO}$ or a homogeneous emphysema as compared with a medically treated group [5]. In patients who survived the procedure, the quality of life was not better than after medical treatment, and a limited benefit with regard to lung function and exercise testing was noted [5]. It is unclear whether bilateral LVRS has better results than the single one. Another question is whether classical surgical procedures are doing better versus the thoracoscopic LVR [6]. Also, the technique to be applied, laser or staple method, is questionable, since the laser technique was found to result in a higher mortality rate [7]. Does sternotomy offer better results and better patient comfort than lateral thoracotomy [7]? Finally, the NETT [8], OBEST [9], and Canadian
LVR [10] trials may fail to answer important questions such as risks and benefits of LVRS, as the patients' enrollment failed to be as predicted. Also the question which patients should be referred for LVRS is still pending, since the patients' profile in trials is different [11].

Nowadays, flexible fiberoptic bronchoscopy (FFB) has been largely applied for diagnosis and therapy of lung diseases. Its simplicity together with the wide application and better physician knowledge made this procedure a major tool in pneumonology $[12,13]$. There are recent reports using FFB for LVR [14, 15]. Experiments performed in sheep showed that LVR was possible by FFB using a biocompatible fibrin-based glue system [14]. The success rate was 55\% in healthy animals [14] and $91 \%$ in animals with a papain-induced experimental emphysema [16]. The lung function parameters showed improvement in this animal emphysema model [16].

Lately, a second team performed bronchoscopic LVR (BLVR) by using a valve implant in a unilateral setting [15]. This phase II pilot study was done in 8 patients with a severe emphysema (median $\mathrm{FEV}_{1} 23.7 \%$ predicted). They placed the valves in all segmental airways leading to the upper lobe most affected by bullae. The procedure was performed under a combined propofol-remifentanil anes-

\begin{tabular}{ll}
\hline KARGER & ( ) 2004 S. Karger AG, Basel \\
Fax +41613061234 & 0025-7931/04/0713-0214\$21.00/0 \\
$\begin{array}{l}\text { E-Mail karger@karger.ch } \\
\text { www.karger.com }\end{array}$ & $\begin{array}{l}\text { Accessible online at: } \\
\text { www.karger.com/res }\end{array}$
\end{tabular}

Demosthenes Bouros, MD, FCCP

Department of Pneumonology

University Hospital of Alexandroupolis

GR-68100 Alexandroupolis (Greece)

Tel./Fax +3025510 76106, E-Mail bouros@med.duth.gr 
thesia. BLVR was successful in 4 patients (50\%), and improvement persisted during the follow-up period. Two patients developed pneumothorax (25\%), and 3 had acute exacerbations of chronic obstructive pulmonary disease. Improvement of the lung function was noted only in patients with successful BLVR [15].

In a recent issue of Respiration, the same authors describe the methodological aspects of this approach [17]. They give details about physician's training, team coordination, and anesthesia and a step-by-step approach of the procedure [17]. Despite the difficulties of targeting the right area, which may explain the low success rate in the first study [15], concept and realization of such an attempt are exceptional. It is necessary that this method will be further developed in order to be more effective. The next step must be phase III studies comparing BLVR with valve implants in LVRS in patients with a severe emphysema [11]. The method should enable physicians to apply a simple, safe, and cost-effective therapy to patients with end-stage chronic obstructive pulmonary disease. It may also change completely the physicians' way of thinking, considering BLVR in the management of late-stage emphysema patients. Furthermore, this method shows the wide area of applications of FFB in the the new millennium.

\section{References}

1 Gelb AF, Brenner M, McKenna RJ Jr, Zamel $\mathrm{N}$, Fischel R, Epstein JD: Lung function 12 months following emphysema resection. Chest 1996;110:1407-1415.

2 Cooper JD, Patterson GA, Sundaresan RS, Trulock EP, Yusen RD, Pohl MS, Lefrak SS: Results of 150 consecutive bilateral lung volume reduction procedures in patients with severe emphysema. J Thorac Cardiovasc Surg 1996;112:1319-1330

3 Martinez FJ, de Oca MM, Whyte RI, Stetz J, Gay SE, Celli BR: Lung-volume reduction improves dyspnea, dynamic hyperinflation, and respiratory muscle function. Am J Respir Crit Care Med 1997;155:1984-1990.

4 Geddes D, Davies M, Koyama H, Hansell D, Pastorino U, Pepper J, Agent P, Cullinan P, MacNeill SJ, Goldstraw P: Effect of lung-volume-reduction surgery in patients with severe emphysema. N Engl J Med 2000;343:239245.

5 The National Emphysema Treatment Trial Research Group: Patients at high risk of death after lung-volume-reduction surgery. N Engl J Med 2001;345:1075-1083.

6 Krucylak PE, Keller CA, Naunheim KS: Current status of thoracoscopic lung volume reduction. World J Surg 1999;23:1148-1155.
7 Stirling GR, Babidge WJ, Peacock MJ, Smith JA, Matar KS, Snell GI, Colville DJ, Maddern GJl: Lung volume reduction surgery in emphysema: A systematic review. Ann Thorac Surg 2001;72:641-648.

8 The National Emphysema Treatment Trial Research Group: Rationale and design of the National Emphysema Treatment Trial (NETT): A prospective randomized trial of lung volume reduction surgery. J Thorac Cardiovasc Surg 1999; 118:518-528.

9 Principal Investigators of OBEST: The Overholt Blue Cross Emphysema Surgery Trial: A multicenter clinical trial on lung volume reduction surgery. Mass Thorac Soc Newslett 1998; 2:1-3.

10 Miller JD, Malthaner RA, Goldsmith CH, Cox G, Higgins D, Stubbing D, Kitching A, Newman TE, McDonald E: Lung volume reduction for emphysema and the Canadian Lung Volume Reduction Surgery (CLVR) Project. Can Respir J 1999;6:26-32.

11 Berger RL, Celli BR, Meneghetti AL, Bagley $\mathrm{PH}$, Wright CD, Ingenito EP, Gray A, Snider GL: Limitations of randomized clinical trials for evaluating emerging operations: The case of lung volume reduction surgery. Ann Thorac Surg 2001;72:649-657.
12 Vergnon JM, Froudarakis M: Bronchoscopy; in Grassi C, Brambilla C (eds): Pulmonary Diseases. Clinical Medicine Series. London, McGraw-Hill International, 1999, pp 39-43.

13 Froudarakis M, Bouros D, Siafakas N: Endoluminal metastases of the tracheobronchial tree: Is there any way out? Chest 2001;119:679_ 681.

14 Ingenito EP, Reilly JJ, Mentzer SJ, Swanson SJ, Vin R, Keuhn H, Berger RL, Hoffman A: Bronchoscopic volume reduction: A safe and effective alternative to surgical therapy for emphysema. Am J Respir Crit Care Med 2001; 164:295-301.

15 Toma TP, Hopkinson NS, Hillier J, Hansell DM, Morgan C, Goldstraw PG, Polkey MI, Geddes DM: Bronchoscopic volume reduction with valve implants in patients with severe emphysema. Lancet 2003;361:931-933.

16 Ingenito EP, Berger RL, Henderson AC, Reilly JJ, Tsai L, Hoffman A: Bronchoscopic lung volume reduction using tissue engineering principles. Am J Respir Crit Care Med 2003;167: 771-778.

17 Toma TP, Polkey MI, Goldstraw PG, Morgan C, Geddes DM: Methodological aspects of bronchoscopic lung volume reduction with a proprietary system. Respiration 2003;70:658664. 